\title{
Linkage Between Self-Control, Financial Innovations and Financial Inclusion. A Moderated Mediation Analysis Across Levels of Financial Literacy (The case of owners of Microenterprise in Kenya)
}

\author{
Byegon Gladys
}

\begin{abstract}
Financial Inclusion has been conjectured as a driver of social development with benefits accruing both at micro and macro levels. Finance theory suggest that behavioral factors influence the utilization of financial services and adoption of emerging innovations and that financial has an effect on optimal usage of financial services. Studies that examines the combined effects of behavioral factors, financial innovations and financial literacy in determining the effect on utilization of financial services are scanty, yet the latter is deemed as a key driver in realization of a number of United Nation's Sustainable Development Goals (2030). The study extended prior suppositions by integrating the three variables into a novel model of moderated mediation. Thus, the linkage between self-control, which is a behavioral factor, adoption of financial innovations and utilizations of diverse everyday financial services was examined. The relationship between the three variables was further tested for the moderating effects of various levels of financial literacy of the sampled users of the financial services. Data was collected using a structured questionnaire from the randomly sampled owners/or their representatives of microenterprises in Nairobi, Kenya. The hypotheses were tested using relevant models in Process Macro [52]. The conditional indirect effects were attested, thus the conclusion that financial innovations mediates the selfcontrol and financial inclusion relations if entrepreneurs hold sufficient levels of financial literacy. The strength of the mediated effect varied with levels of financial literacy. Implications for theory growth and policy interventions are discussed.
\end{abstract}

Index terms - Behavioral Factors, Financial Inclusion, Financial Innovations, Financial Literacy, and Self-Control.

\section{INTRODUCTION}

Financial Inclusion (FI) generally viewed as the process of enhancing access and usage of formal financial services has emerged as an area of global concern and study. The positive relationship between growth in the financial services sector, economic development and financial inclusion is agreeable to many finance scholars [2], [3], [4]. To fortify this theory, diverse research has been undertaken by policy entities such as the World Bank. [5]. The argument is that through the mobilization of savings, FI helps in the injection of additional capital to the financial markets which can then be loaned to those in need, hence reducing capital constraints faced by financial institutions in addition to promoting growth and profitability of financial services providers. Furthermore, FI helps to enhance people's income earning potential thus reducing poverty levels, especially for the vulnerable groups, while also reducing financial risks during turbulent times through mobilization of funds from one's social network. [6]. Indeed, while recognizing the positive nexus between finance and economic growth, and its role in the realization of approximately $41 \%$ of the Sustainable Development Goals (SDGs), there is a drive for universal FI from access point of view [7], [8]. Although FI is commonly viewed from access (ability to use) point of view, other dimensions of the phenomenon exists which includes: availability, level of usage, quality of financial services as well as welfare that entails the impact of the services on users [9], [10]. Usage has been conjectured as a key measure of FI because it is through active usage of FS that benefits are realized [1], [10].

Based on prior studies, there seems to be consensus on the critical role of FI both at micro and macro levels, however, there is inadequacy of empirical data on the factors that reinforce the same, thus a growing body of knowledge in this path. Most studies on the financial inclusion phenomenon have focused on effects of demographic factors. In addition, prior studies have dwelt on the direct of behavioral factors, financial innovations and financial literacy on usage of financial services (financial inclusion). Scanty research have empirically examined how the three variables interact to influence usage of everyday financial services, a gap which if filled may unlock the potential for optimal usage of financial services, to enhance realization of majority of the Sustainable Development Goals by the year 2030 .

Taken together, the purposes of the present study were threefold. The study sought to move beyond the examination of direct effects of the three variables on the utilization of

Published on July 30, 2020.

Gladys Byegon, Moi University, School of Business \& Economics, Kenya.

(corresponding e-mail: gladchero10@gmail.com) 
financial services by owners of microenterprises, by first investigating the mediating effects of financial innovations on the self-control and financial inclusion relations. Secondly, the study explored the moderating effects of financial literacy on the relationship between self-control and financial inclusion. Thirdly, the study explored the moderated mediated (conditional indirect) effects of financial literacy on the relationship between self-control and financial inclusion via financial innovations at different levels of the moderator.

\section{LITERATURE REVIEW}

There are four variables in this study, self-control that is a form of behavioral factors modeled as the independent variable, financial innovations (mediator), financial literacy (moderator) and financial inclusion (utilization of ordinary financial services) as the dependent variable.

\section{A. Behavioral Factors}

Behavioral finance theory recognizes the impact of psychological or behavioral factors (BF) such as risk aversion, overconfidence, imitation, and self-control among others biases on financial decisions [11], [12], [13], [14]. A growing number of studies on users of financial services also referred to as consumer finance has focused on the behavioral biases in their quest to understand their role in financial decisionmaking. Some studies have associated the behavioral biases with sub-optimal financial decision-making, for example, consumers' preference for materialism may lead to higher indebtedness, as is the case with lack of self-control, an indicator of present biasness reflected in form of compulsivity and impulsiveness with severe detrimental effects such as high indebtedness and low accumulation of wealth [15], [16], [17]. On the contrary, positive BF such as possession of self-control, confidence in the use of financial information, deliberate thinking, optimism, willingness to take informed risks have been suggested to lead to optimal usage of FS [11], [14], [18], [19]. However, studies that recognize BF on commonly used financial services, a departure from assets traded in securities markets as used in earlier behavioral finance studies, are at infancy stage hence the need to contribute to knowledge growth [17], [20], [21], [22]. Thus, this study contributed to enrichment thereof with attention being on self-control, which is one of the BF, theorized to influence financial decisions. The study unit was the owners of microenterprises and focus was on their decision making as utilization of ordinary financial services available in Kenya.

\section{B. Financial Innovations}

There is a strand of studies that have dwelt on basis of adoption of financial innovations (FINN) using established theories such as the Technology Acceptance Model, with factors such as perceived usefulness, ease of use, credibility, self-efficacy, and financial cost among others [23], [24]. These emerging innovations in the financial sector encompasses mobile financial or money services, internet banking, card payment systems, and agency banking among others, and they can be broadly classified into three categories; those that provide new delivery channels, new products and new types of financial intermediaries [1], [2], [6], [25], [26]. Theory suggests that FINN has the potential of enhancing FI through expanding opportunities for access and utilization of diverse FS. However, there is scanty research on diverse aspects of FINN such as information, digital credit and investments, effects of innovations on financial stability among others [27], [28], [29], [30]. Besides, FINN has the potential of fostering positive behavioral factors and financial discipline, for example, some studies suggest that reminders through short message service (SMS) may lead to increased savings [31], [32] and enhanced loan repayment [27], [33]. In addition, scholars have highlighted the impact of FINN on modification of behavior for enhanced usage of financial services such as encouraging savings by appealing to peoples' gambling tendencies as well as the provision of price or lottery linked financial products or accounts [43]. Informed by prior research studies, the relationship between FINN, diverse behavioral factors and utilization of financial services was examined in an earlier study [19] however, the hypothesized interaction between the three variables and financial literacy informed the present study.

\section{Financial Literacy}

Financial literacy (FL) continues to play an ever-increasing role in financial and economic domains through effects it has on decision making with effects ranging from individual to macro levels. FL has not been unanimously [34], [35], however, extant literature considers the construct from two main perspectives; ability to understand financial information and usage thereof to make informed money related decisions [36], [37], [38]. Extant literature have theorized the relationship between FL and financial decision-making on areas such as savings, investments and debt management as well as enhancing information and users' confidence that then drives demand for FS [39], [40].

Finance Theory has it that individuals with low FL do not actively participate in financial markets, have fewer assets, make sub-optimal financial decisions such as having high consumption rates, borrowing at higher interest rates, easily fall prey to financial scams, save less and have low capacity to handle macroeconomic shocks, among others [36], [37], [41], [42], [43]. Emerging studies such as [34], conjectures that financial literacy has moderating effects on the relationship between behavioral tendencies and investment decisions. Whereas a growing number of studies recognize the place of FL in financial decision-making, the moderating role of FL on the BF-FI relations has been seldom pursued in consumer finance subfields, as has been the case in corporate finance subfields such as [62], [63], hence the moderation test is of the main contributions of this study. 
Following the outcome of the literature review, the researcher formulated the three hypotheses outlined below and the moderated-mediation model (Fig. 1) to guide the study:

Hypothesis 1: Adoption of financial innovations mediates the self-control and financial inclusion relations.

Hypothesis 2: Financial literacy moderates the direct relationship between self-control and financial inclusion.

Hypothesis 3: Financial literacy has moderating effects on the indirect relations between self-control and financial inclusion through financial innovations. Further, that the moderation of the indirect relationship would be higher at high levels of financial literacy.

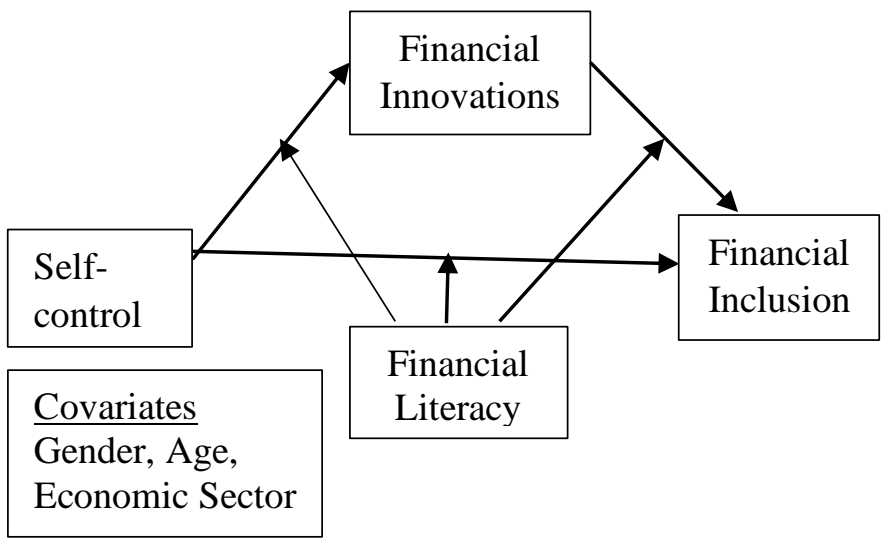

Fig. 1: Conceptual Framework for the Study (Researcher, 2019).

\section{A. Design and Participants}

The research philosophy adopted by the researcher leaned towards the post-positivism paradigm [44], given that quantitative data was collected to generate knowledge through testing of the main theoretical framework for the study, Behavioral Finance Theories. Primary data was collected from owners/representatives of owners of microenterprises. Using Yamane (1967) formulae in [45], a sample of 486 owners of microenterprises in Embakasi East, Nairobi, Kenya was selected. Data was successfully collected from 413 participants $(84.9 \%)$ which was greater than 50 percent, hence considered adequate for further analysis [46].

\section{B. Measurements}

Financial inclusion was measured through seven items that gauged perceptions on commonly used financial services; payments, money transfer services, savings, credit and investments all undertaken through formal financial institutions. The items were selected from those in financial inclusion surveys such as [6], [47], [67] among others. Selfcontrol was measured using that gauged respondent's behavioral tendencies as regards usage of the financial services. The items were derived from prior studies such as [14], [16]. FINN was measured using perceptions on adoption of emerging financial products, new channels and intermediaries as well as information on usage of FS [26], [33]. Financial literacy was measured using the objective method, whereby participants answered questions that gauged their knowledge on risk diversification, inflation/ time value for money, numeracy, compound interest and formal financial institutions in Kenya [34], [36], [49]. Prior studies such as [6], [25], [36], [49], [50], informed the identification of covariates for the study (age, gender and main economic activity) in order for the model to account for known effects of demographic factors. I adapted each of the items in the research variables to Kenya's environment.

\section{Statistical Analysis}

The researcher first derived descriptive statistics for the variables of interest and covariates then assessed bivariate associations. Thereafter, statistical analysis for the research was undertaken using Model 4 (Mediation) and Model 59 of Process Macro [52] to test the relationship between selfcontrol, adoption of financial innovations, financial literacy levels and financial inclusion. Model 59 tests both the conditional direct effects (moderation) and the moderated mediation effects (conditional indirect effects) the latter of which investigates whether the degree of a mediation effect is conditional on the value of a moderator. The Process Macro uses bootstrapping method to test for the significance of the effects, which exists if the confidence intervals (CI) of the outcome of the resampled data, excludes zero [53], [54], [55]. For this study, the results of the bootstrapping method were 95\% bias-corrected CI of the effects arising from 5,000 resamples of the data [52] and interpretations were made on the significance of the effects as per the hypotheses.

\section{RESULTS}

\section{A. Data Cleaning}

Data screening and cleaning was undertaken to identify missing data and outliers determined using Cook's and Mahalanobis distances tests within SPSS, correction of which were winsorized to minimize impact on the research model. [48].

\section{B. Reliability and Validity Tests}

To tests reliability of the data collection tool and outcome, tests were undertaken using Cronbach's Alpha for items measured using Likert type questions. [56]. The results of the tests on the three variables (FI, Self-control, and FINN) and were all within the acceptable levels of 0.7. [57]. Validity test on the measurement items for each variable were undertaken using factor analysis (principal component analysis with variable maximization (Varimax), with a cutoff of 0.4 [58]. The results are present in Table I below. 
TABLE I: RELIABILITY AND VALIDITY TESTS

\begin{tabular}{|c|c|c|c|}
\hline$n=413$ & $\begin{array}{l}\text { Mean } \\
\text { loadings }\end{array}$ & AVE & CV\% \\
\hline $\begin{array}{l}\text { FI (Cronbach's Alpha }=.731, \mathrm{KMO}=.694, \\
\text { Bartlett's Test of Sphericity=2063.81*, } \\
\text { SD =0.623; Skew= 0.232) }\end{array}$ & 3.00 & 0.83 & 84.84 \\
\hline $\begin{array}{l}\text { Self-Control (Cronbach's Alpha }=.887 \text {, } \\
\text { KMO }=.783 \text {, Bartlett's Test of Sphericity= }\end{array}$ & & & \\
\hline $1662.839 * ; \mathrm{SD}=0.752 ; \mathrm{Skew}=-0.116)$ & 3.00 & 0.69 & 69.40 \\
\hline $\begin{array}{l}\text { FINN (Cronbach's Alpha }=.920, \mathrm{KMO}=.729, \\
\text { Bartlett's Test of Sphericity }=7178.931 * \\
\text { SD }=0.695 ; \text { Skew }=-0.149\end{array}$ & 3.17 & 0.40 & 87.06 \\
\hline$* p<0.05$ & & & \\
\hline
\end{tabular}

For financial literacy, which did not use Likert type questions, the results of the objective assessment was assessed depending on correct scores on the six questions (referred to as FLsc) for each of the respondents. The outcome of which was used for computation of descriptive statistics (Mean = 3.066; standard deviation $=1.08767$ ).

Thereafter, the data was subjected to various tests of assumptions of multiple regression equations; normality, linearity, and heteroscedasticity, their results of which were satisfactory [48], [52].

\section{Bivariate Analysis}

Bivariate analysis were undertaken and the results are provided in Table II below. The researcher observed that there is a positive and significant correlation between the study predictor variables and financial inclusion. Particularly, the correlation results showed that self-control (SC) had a positive and significant moderate relationship with financial inclusion $(r=.592, \rho<.01)$. Financial innovations (FINN) was observed to be positively and significantly correlated with financial inclusion $(r=.385, \rho<.01)$. In addition, financial literacy (FL) had a significant and positive correlation with financial inclusion $(r=.337, \rho<.01)$. Among the covariates, Gender $(r$ $=.0 .021, \rho>.01)$ and age $(r=.007, \rho>.01)$ respectively indicated positive but insignificant correlation with FI, whereas economic sector had a negative but insignificant relation with the dependent variable $(r=-.001 ; \rho>.05)$.

TABLE II: CORRELATION ANALYSIS

\begin{tabular}{|c|c|c|c|c|c|c|c|}
\hline $\mathrm{n}=413$ & FI & SC & FINN & FL & gender & age & sector \\
\hline FI & 1 & & & & & & \\
\hline SC & $.592 * *$ & 1 & & & & & \\
\hline FINN & $.385^{* *}$ & $.388 * *$ & 1 & & & & \\
\hline FL & $.337^{\text {** }}$ & $.232^{* *}$ & $.195^{* *}$ & 1 & & & \\
\hline gender & 0.021 & 0.007 & 0.043 & -0.07 & 0.043 & & \\
\hline age & 0.007 & 0.029 & $0 . \overline{-} 33$ & 0.026 & $.441^{* *}$ & 1 & \\
\hline sector & -0.001 & -0.002 & $\begin{array}{c}- \\
0.029\end{array}$ & 0.051 & $.226 * *$ & $.245^{* * *}$ & 1 \\
\hline
\end{tabular}

**. Correlation is significant at the 0.01 level (2-tailed).

Source: Research Data, 2019.
Based on the results on the multiple regression assumptions and the correlation analysis, linear relationship between the predictor variables and the predicted variable (financial inclusion) were attested, hence giving credence for undertaking of superior analysis through multiple regression models incorporated in the Process Macro [52] for mediation, moderation and moderated mediation.

\section{Mediating Effects of Financial Innovations}

The researcher had conjectured that adoption of financial innovations would mediate the self-control and financial inclusion relations (hypothesis 1). [59] Suggests that mediation analysis is best tested using the bootstrap test of the indirect effect $\left(a^{*} b\right)$. To test the mediation effects, the study utilized Model 4 of Process Macro [52], which incorporates the more sophisticated bootstrapping method. The results are provided in Table III below.

\begin{tabular}{cccc}
\multicolumn{4}{c}{ TABLE III: MEDIATION EFFECTS OF FinANCIAL INNOVATIONS } \\
\hline $\begin{array}{c}\text { Outcome variable } \\
\text { FINN } \\
\text { Coeff }\end{array}$ & $\begin{array}{c}\text { Outcome } \\
\text { variable: FI } \\
\text { Coeff }\end{array}$ & $\begin{array}{c}\text { Indirect } \\
\text { effect: } \\
\text { Coeff } \\
(\mathrm{a} * \mathrm{~b})\end{array}$ \\
\hline $\begin{array}{c}\text { (Constant) } \\
\text { gender }\end{array}$ & -.0583 & -.0208 & \\
age & .0474 & -.0036 & \\
sector & -.0531 & .0089 & \\
$\begin{array}{c}\text { Self-control } \\
\text { Financial }\end{array}$ & -.0499 & .0038 & \\
$\begin{array}{c}\text { Innovation } \\
\text { Indirect } \\
\text { effect: }\end{array}$ & $.3188^{* *}$ & $.4461^{* *}$ & \\
Coeff & & $.2953^{* *}$ & \\
\hline
\end{tabular}

Coeff $\left(a^{*} \mathrm{~b}\right)$

Model Summary: Outcome Variable FI

$\begin{array}{cc}\text { R } & .6040 \\ \text { R Square } & .3648 \\ \text { MSE } & .6482\end{array}$

ANOVA; model fitness

F $\quad 46.7443$

Sig. $\quad .0000$

$* *$ Coeff significant at the 0.05 level (2-tailed).

Direct effect of self-control on FI $=.4461 * *$

Indirect effect of self-control on FI $(\mathrm{a} * \mathrm{~b})=0.0941^{* *}$

Indirect effect (s) of $\mathrm{X}$ on $\mathrm{Y}$ :

Effect BootSE BootLlCI BootULCI

$\begin{array}{lllll}\text { ZFINN } & .0941 & .0269 & .0436 & .1496\end{array}$

Number of bootstrap samples for percentile bootstrap confidence intervals:5000

Source: Research Data, 2019

The results as outlined in Table III above indicates that the mean indirect effect from the bootstrap analysis of 5,000 resamples is positive and significant $\left(\beta=0.0941^{* *}, \rho=0.00\right)$ with a $95 \%$ confidence interval excluding zero (BootLLCI $=.0436$; BootULCI $=.1496)$. The direct effect $\left(c^{\prime}=.446\right)$ is also positive and significant. Furthermore, the product of $\mathrm{a}^{*} \mathrm{~b} * \mathrm{c}(=0.3188$ 
$* 0.2953 * 0.4461)$ is positive hence the mediation effects in the model were complimentary [59]. Therefore, the researcher concluded that financial innovations significantly mediated the relationship between self-control and financial inclusion; thus supporting the suggestions in hypothesis one.

\section{E. Conditional Direct Effects of Financial Literacy}

The Researcher utilized Model 59 of the Process Macro [52] that was considered useful in understanding the moderated mediation relationship (conditional indirect effects) under investigation. The conditional process provides results on the moderated direct relationship (conditional direct effects) for testing hypothesis 2 and the moderated mediated relationship (conditional indirect effects) as per hypothesis 3. Examination of the results of the $95 \%$ CI was made to determine whether moderation and the moderated mediation exists or otherwise. [53]. The results of the analysis are outlined in Table IV below.
The results for hypothesis 2 , conditional effects of financial literacy on the self-control and financial inclusion relations are outlined in part (a) of Table IV below. The outcome indicates that financial literacy had significant moderating effects on the relationship between self-control and financial inclusion as attested by the confidence intervals at each of the three levels; (BootLLCI $=0.0626$, BootULCI $=0.2371$; BootLLCI $=0.2992$, BootULCI=0.4746; BootLLCI=0.4604, BootULCI=0.6831), all of which does not include zero. Furthermore, the conditional direct effect of self-control on financial inclusion is attested by interaction term between the independent (selfcontrol) and the moderator (financial literacy) variables $(\mathrm{X} * \mathrm{~W}$ $=0.0172$ ) is significant given that $\rho<.05$ ) .

TABLE IV: CONDITIONAL DIRECT AND INDIRECT EFFECTS OF FINANCIAL LITERACY

\begin{tabular}{|c|c|c|c|c|c|c|}
\hline \multicolumn{2}{|c|}{ Model: 59} & \multicolumn{5}{|c|}{ Y: ZFI, X= ZSC, W: ZFL Covariates: ZE1, ZE2 \& ZE3 } \\
\hline Model & Coeff & Se & $\mathbf{T}$ & $\mathbf{P}$ & LLCI & ULCI \\
\hline Constant & -0.0243 & 0.0397 & -0.6114 & 0.5413 & -0.1022 & 0.0537 \\
\hline $\mathrm{ZSC}$ & 0.4038 & 0.0430 & 9.3797 & 0.0000 & 0.3191 & 0.4884 \\
\hline ZFINN & 0.2671 & 0.0442 & 6.0395 & 0.0000 & 0.1801 & 0.3540 \\
\hline ZFL & 0.0584 & 0.0404 & 1.4464 & 0.1488 & -0.0210 & 0.1378 \\
\hline Int_1 & 0.1499 & 0.0444 & 3.3775 & 0.0008 & 0.0626 & 0.2371 \\
\hline Int_2 & 0.0253 & 0.0451 & 0.5602 & 0.5757 & -0.0634 & 0.1140 \\
\hline ZE1 & 0.0020 & 0.0442 & 0.0462 & 0.9632 & -0.0848 & 0.0889 \\
\hline ZE2 & 0.0221 & 0.0446 & 0.4958 & 0.6203 & -0.0655 & 0.1097 \\
\hline ZE3 & -0.003 & 0.0408 & -0.0755 & 0.9398 & -0.0832 & 0.07 \\
\hline \multicolumn{7}{|c|}{ Test(s) of unconditional interaction(s): } \\
\hline & R2-chng & $\mathbf{F}$ & df1 & df2 & $\mathbf{P}$ & \\
\hline $\mathrm{X} * \mathrm{~W}$ & 0.0172 & 11.407 & 1.0000 & 404.000 & 0.0008 & \\
\hline $\mathrm{M} * \mathrm{~W}$ & 0.0005 & 0.3138 & 1.0000 & 404.000 & 0.5757 & \\
\hline \multicolumn{7}{|c|}{ Model summary } \\
\hline $\mathrm{R}$ & 0.6250 & & & & & \\
\hline $\mathrm{R}^{2}$ & 0.3906 & & & & & \\
\hline MSE & 0.6265 & & & & & \\
\hline \multicolumn{7}{|c|}{ ANOVA; model fitness } \\
\hline $\mathrm{F}$ & 32.3694 & & & & & \\
\hline Sig. & .0000 & & & & & \\
\hline \multicolumn{7}{|c|}{ Conditional Direct effects of X o } \\
\hline FL & Effect & SE & $\mathbf{T}$ & $\mathbf{P}$ & LLCI & ULCI \\
\hline-0.8985 & 0.2691 & 0.0659 & 4.0856 & 0.0001 & 0.1396 & 0.3986 \\
\hline-0.1123 & 0.3869 & 0.0446 & 8.6744 & 0.0000 & 0.2992 & 0.4746 \\
\hline 1.1205 & 0.5717 & 0.0567 & 10.091 & 0.0000 & 0.4604 & 0.6831 \\
\hline \multicolumn{7}{|c|}{ Conditional Indirect Effects: ZSC -> ZFINN } \\
\hline ZFL & Effect & BootSE & \multicolumn{2}{|c|}{ BootLLCI } & \multicolumn{2}{|c|}{ BootULCI } \\
\hline-0.8985 & 0.0409 & 0.0254 & -0.0019 & & 0.0972 & \\
\hline-0.1123 & 0.0701 & 0.0223 & 0.0303 & & 0.1170 & \\
\hline 1.1205 & 0.1238 & 0.0488 & 0.0441 & & 0.2325 & \\
\hline
\end{tabular}

Level of confidence for all confidence intervals in output: 95.0000 .

Number of bootstrap samples for percentile bootstrap confidence intervals: 5000 .

$\mathrm{W}$ values in conditional tables are the 16th, 50th, and 84th percentiles

Source: Research Data, 2019 
The labels for the variables in the Table IV above comprise of $\mathrm{FI}=$ Financial Inclusion, $\mathrm{SC}=$ Self-control, FINN = Financial innovations, FL=Financial literacy, E1= Gender, E2= Age and E3= Sector.

The outcome of the conditional direct effects of financial literacy on the relationship between self-control and financial inclusion is further demonstrated in Fig. 2 below.

The Researcher observed that whereas the moderated relationship exist at all levels of interactions, the effects are higher at high levels of Financial Literacy (one standard deviation above the mean), as evidenced by the steeper gradient of the upper line graph as compared to the lower level (one standard deviation below the mean). The moderation graph (ModGraph) was computed using the online programme developed by [60]. The Researcher concluded that financial literacy significantly moderates the self-control and financial inclusion hence empirical confirmation of the suggestions as per hypothesis 2 .

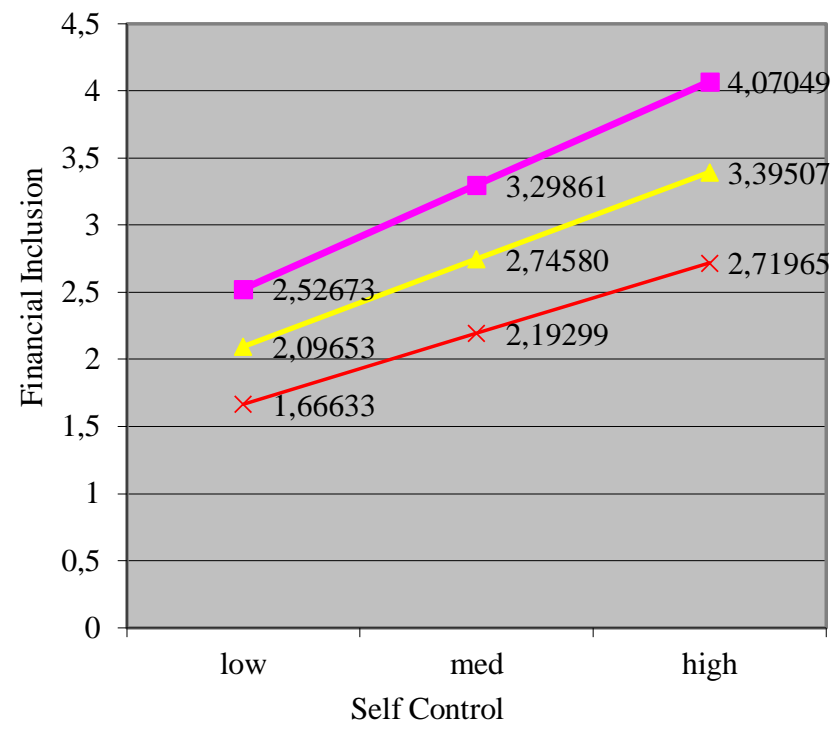

Fig. 2: Conditional Direct Effects of Financial Literacy Source: Research Data, 2019

\section{F. Conditional Indirect Effects Process Modeling}

As provided in hypothesis 3, the Researcher examined the moderated mediation effects of financial literacy, and whether the indirect relationship between self-control and whether the effects would vary at different levels of financial literacy.

The results of the $95 \% \mathrm{CI}$ at the three levels are provided in part (b) (ZSC -> ZFINN -> ZFI) of Table IV above. The study observed that at the lower level $\left(16^{\text {th }}\right.$ percentile; BootLLCI=.0019 , BootULCI $=0.0972$ ) the effects were insignificant given that the confidence level included zero. However, significant conditional indirect effects were observed at the middle level $\left(50^{\text {th }}\right.$ percentile; BootLLCI=.0303; BootULCI=0.1170) and upper levels $\left(84^{\text {th }} \quad\right.$ percentile; BootLLCI=.0441; BootULCI $=0.2325$ ) which both excluded zero. Thus, the results upheld the suggestions of hypothesis 3 of the study, which had predicted that the conditional indirect effects of financial literacy on the indirect relation between Self-control and financial inclusion through financial innovations exits and is higher at high levels of financial literacy.

The conditional indirect effects are further presented through Fig. 3 below, which demonstrates diversity in levels of conditional indirect effects of financial literacy at different levels as depicted by the steepness of the slope of the line graphs. The upper line presents effects at one standard deviations above the mean, whereas the lower line represents effects at one standard deviations below the financial literacy's mean value. The middle line represents the conditional indirect effects at financial literacy mean value of 3.0666 and standard deviation (SD) of 1.08767 .

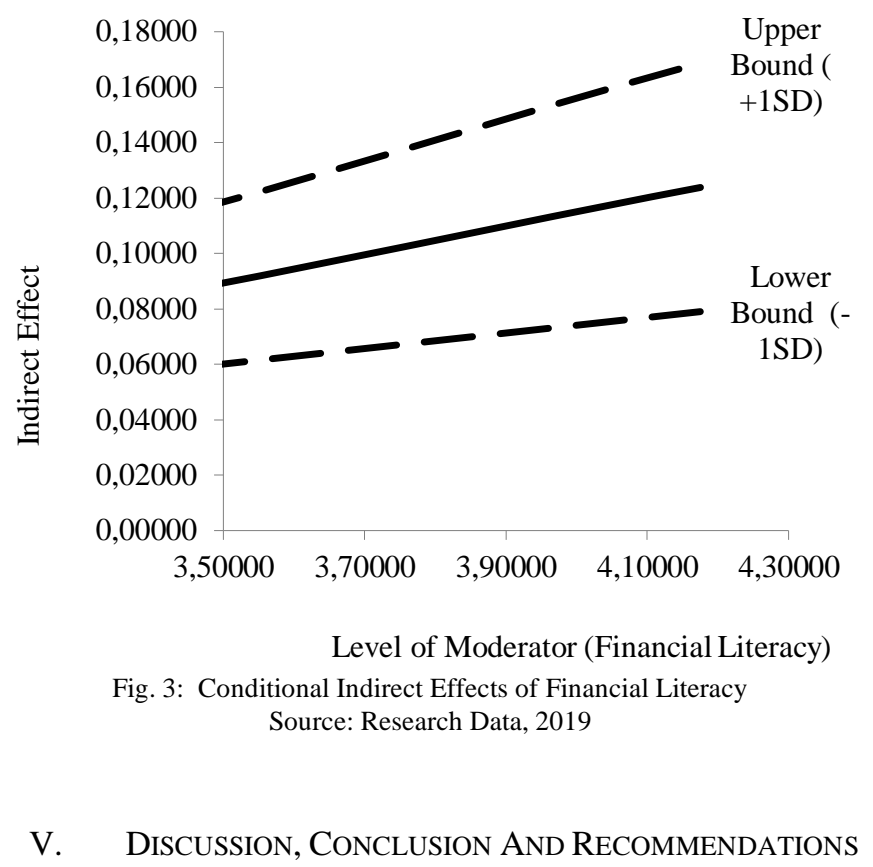

The impact of self-control among other behavioral factors on utilization of diverse forms of formal financial services (financial inclusion) continues to gain empirical interest from scholars and experts [11], [14], [36], [51], [67]. This study formulated a conditional indirect effect model to examine whether self-control would be related to financial inclusion via financial innovations and whether financial literacy would moderate the relationship. The study found out that adoption of financial innovations significantly augments usage of common forms of formal financial services. Further that whereas financial literacy was confirmed to significantly moderating effects, higher levels of financial literacy had higher moderating effects on the indirect relationship between selfcontrol and financial inclusion.

Whereas adoption of innovations has been demonstrated as a mediator in other finance subfields such corporate finance 
[62], [63], little attention has been given to it in other subfields such as consumer finance. The present study is one of the few ones, which have empirically tested the mediating effects of adoption of financial innovations in the self-control and financial inclusion relationship. The findings progresses the previous studies that have dwelt on drivers of financial inclusion (including financial innovations such as digital finance, agency banking among others) from direct relationship point of view and those from behavioral finance standpoint that have focused on effects of psychological and social factors on financial decision making. The two fields have largely developed independently, hence this study in a novel way, brought the two together.

In addition, the results of the second and third goals of the study demonstrates significant moderating effects of financial literacy on the direct relationship between self-control and financial inclusion as well as the indirect relations between the two variables via financial innovations. The two add to the growing body of knowledge based on capability theories that recognize the key role financial literacy in financial decisionmaking. [37], [39], [41], [42], albeit from direct relationship point of view. The findings of the study is in line with earlier findings by [34] on the moderating role of financial literacy on relationship between behavioral factors and usage of financial services.

Whereas studies that examine the moderating role of financial literacy continues to be an interest in the finance field, [19], [34], [65], [66], the novel way through which the conditional indirect effects of financial literacy were empirically demonstrated through this study is a key contribution to the finance field. The significant conditional indirect (moderated mediated) effects observed calls for further studies to enhance theory building on the budding field with a focus on consumers of different forms of formal financial services.

The key role of behavioral finance which recognizes the effects of psychological and social factors in shaping financial decisions, as attested by the outcome of this and prior studies in the field, demonstrates that formal financial service providers should give the theories the attention they deserve and incorporate them in their policy and product formulation processes. The study further recommends that finance experts and scholars should give due attention to financial innovations and financial literacy in their quest to understand and drive policy formulation for enhanced financial inclusion. Studies should move beyond understanding the direct effects of drivers of financial inclusion and graduate to interaction of the variables as mediators or moderators for overall understanding of the underlying linkages. This will go a long way in driving optimal utilization of formal financial services for enhanced wellbeing at both macro and macro levels, thus realization of the Unite Nation's Sustainable Development Goals by the year 2030.

\section{LiMitations \& AREAS FOR FURTHER RESEARCH}

A number of limitations affected the study, for example, the data utilized was cross-sectional and thus it would be prudent to find out if the relationship holds in a time series scenario. Furthermore, whereas this study unpacked the interaction between the four variables (self-control, financial innovations, financial literacy and financial inclusion), further replication and extension are needed in other contexts inclusive of other variables that have been theorized to affect financial inclusion.

\section{REFERENCES}

[1] Beck, T. "Financial Inclusion-Measuring progress and progress in measuring". $4^{\text {th }}$ IMF Statistical Forum Lifting the Small Boats: Statistics for Inclusive Growth. Cass Business School, City, University of London, CEPR, and CESifo, 2016.

[2] Gwalani, H. \& Shilpa, P. (2014). "Financial Inclusion: Building a Success Model in the Indian Context". Journal of Social and Behavioral Sciences. 13(3), 372-378.

[3] Sethi, D., \& Acharya, D. "Financial inclusion and economic growth linkage: Some cross country evidence". Journal of Financial Economic Policy, 10(3), 369-385, 2018.

[4] Sharma, D. "Nexus between financial inclusion and economic growth: Evidence from the emerging Indian economy". Journal of Financial Economic Policy, 8(1), 13-36, 2016.

[5] World Bank. "Global Financial Development Report 2014: Financial Inclusion". Washington, DC: World Bank, (2014).

[6] Demirguc-Kunt, A., Klapper, L., Singer, D., Ansar, S., \& Hess, J. "Global Findex Database 2017: Measuring Financial Inclusion and the Fintech Revolution". Washington, DC: World Bank, 2018.

[7] Gupta, J., \& Vegelin, C. "Sustainable development goals and inclusive development". International environmental agreements: Politics, law and economics, 16(3), 433-448, 2016.

[8] World Bank. "Global Financial Development Report 2017/2018: Bankers without Borders". Washington, DC: World Bank. doi:10.1596/978-1-4648-1148-7. License: Creative Commons Attribution CC BY 3.0 IGO, 2018.

[9] Jukan, M. K., \& Softić, A. "Comparative analysis of financial inclusion in developing regions around the world". Economic Review: Journal of Economics and Business, 14(2), 56-65, 2016.

[10] Sarma, M. "Index of financial inclusion" Working paper, No. 215, 2008.

[11] Singh, R., \& Roy, S. "Financial Inclusion: A Critical Assessment of its Concepts and Measurement". Asian Journal of Research in Business Economics and Management, 5(1), 12, 2015.

[12] Gathergood, J. "Debt and Depression: Causal Links and Social Norm Effects". The Economic Journal, 122(1), 1094-1114, 2012.

[13] Jurevičienè, D., \& Ivanova, O. "Behavioral finance: theory and survey". Science-Future of Lithuania, 5(1), 53-53, 2013.

[14] Odean, T., \& Barber, B. "The courage of misguided convictions: the trading behavior of individual investors". Financial Analyst Journal, 41$55,1999$.

[15] Strömbäck, C., Lind, T., Skagerlund, K., Västfjäll, D., \& Tinghög, G. "Does self-control predict financial behavior and financial wellbeing?" Journal of Behavioral and Experimental Finance, 14, 30-38, 2017.

[16] Ameriks, J., Andrew C., John L., \& Tom T. "Measuring self-control problems". American Economic Review, 97(3), 966-972, 2007.

[17] Nye, P., \& Hillyard, C. "Personal financial behavior: The influence of quantitative literacy and material values". Numeracy, 6(1), 3, 2013.

[18] Peltier, J. W., Pomirleanu, N., Endres, M., \& Markos, E. Psycho-social factors impacting credit acquisition and use by college students. In Financial Literacy and the Limits of Financial Decision-Making (pp. 177-200). Palgrave Macmillan, Cham, 2016.

[19] Benton, M., Meier, S., \& Sprenger, C. "Over borrowing and under saving: Lessons and policy implications from research in behavioral economics". Federal Reserve Bank of Boston Community Affairs Discussion Paper, 7(4), 2007. 
[20] Byegon, G., Cheboi, J., \& Bonuke, R. "Mediating Effects of Financial Innovations between Behavioral Factors and Financial Inclusion of Micro Enterprises in Kenya". SEISENSE Journal of Management, 2(6), 49-64, 2019.

[21] Binoy, T., \& Subhashree N. "Behavioural factors that influence the continued usage of formal financial services among the low-income households". International Journal of Mechanical Engineering \& Technology, 9 (7), 22-36, 2018.

[22] Rahmawati, D., \& Asandimitra, N. "The Influence of Demography, Social Environment and Financial Self-Efficacy toward Saving Behavior". In 2nd Social Sciences, Humanities and Education Conference: Establishing Identities through Language, Culture, and Education (SOSHEC 2018). Atlantis Press, 2018.

[23] Waweru, N. M., Mwangi G. G., \& John M. P. "Behavioural factors influencing investment decisions in the Kenyan property market". AfroAsian Journal of Finance and Accounting vol. 4, issue 1, 26-49, 2014.

[24] Jeong, B. K., \& Yoon, T. E. "An empirical investigation on consumer acceptance of mobile banking services". Business and Management Research, 2(1), 31-40, 2013.

[25] Munoz-Leiva, F., Climent-Climent, S., \& Liébana-Cabanillas, F. "Determinants of intention to use the mobile banking apps: An extension of the classic TAM model". Spanish Journal of Marketing-ESIC, 21(1), 25-38, 2017.

[26] Siddik, M. N. A., Sun, G., Yanjuan, C. U. I., \& Kabiraj, S. "Financial inclusion through mobile banking: a case of Bangladesh". Journal of Applied Finance and Banking, 4(6), 109, 2015.

[27] Cadena, X., \& Schoar, A. "Remembering to pay? Reminders vs. financial incentives for loan payments (No. w17020)". National Bureau of Economic Research, 2011.

[28] Francis, E., Blumenstock, J., \& Robinson, J. "Digital credit: A snapshot of the current landscape and open research questions". Bureau for Research and Economic Analysis of Development Working Paper, 516, 2017.

[29] Ozili, P. K. "Impact of digital finance on financial inclusion and stability". Borsa Istanbul Review, 18(4), 329-340, 2018.

[30] Yeo, J. H., \& Fisher, P. J. "Mobile Financial Technology and Consumers' Financial Capability in the United States". Journal of Education \& Social Policy, 7(1), 33-51, 2017.

[31] Kast, F., Meier, S., \& Pomeranz, D. "Saving more in groups: Field experimental evidence from Chile". Journal of Development Economics, 133, 275-294, 2018.

[32] Karlan, D., McConnell, M., Mullainathan, S., \& Zinman, J. "Getting to the top of mind: How reminders increase saving (No. w16205)". NBER Working Paper. Retrieved from www. nber. org/papers/w1620, 5, 2010.

[33] Jones, L. E., Loibl, C., \& Tennyson, S. "Effects of informational nudges on consumer debt repayment behaviors". Journal of Economic Psychology, 51, 16-33, 2015.

[34] Aren, S. \& Aydemir, S. "A Literature Review on Financial Literacy". Finansal Araştırmalar ve Çalışmalar Dergisi. 11. 33-49. 10.14784/JFRS.2014117326, 2014.

[35] Huston, S. J. "Measuring financial literacy". Journal of Consumer Affairs, 44(2), 296-316, 2010.

[36] Klapper, L., Lusardi, A., \& Van Oudheusden, P. "Financial literacy around the world: Insights from the Standard \& Poor's ratings services global financial literacy survey". 2015, Retrieved from https://gflec.org/wp-content/uploads/2015/11/3313Finlit_Report_FINAL-5.11.16.pdf?x68973

[37] Lusardi, A., \& Mitchell, O. S. "The Economic Importance of Financial Literacy: Theory and Evidence". Journal of Economic Literature, American Economic Association, 52(1), 5-44, 2014.

[38] Servon, L. J., \& Kaestner, R. "Consumer financial literacy and the impact of online banking on the financial behavior of lower-income bank customers". Journal of Consumer Affairs, 42(2), 271-305, 2008.

[39] Grohmann, A. "Financial literacy and financial behavior: Evidence from the emerging Asian middle class". Pacific-Basin Finance Journal, 48, 129-143, 2018.

[40] Grohmann, A., Klühs, T., \& Menkhoff, L. "Does Financial Literacy Improve Financial Inclusion?" World Development, Elsevier, 111(C), 8496, 2018
[41] Cole, S., Sampson, T., \& Zia, B. "Prices or knowledge? What drives demand for financial services in emerging markets?" The journal of finance, 66(6), 1933-1967, 2011.

[42] Lusardi, A., Mitchell, O. S., \& Curto, V. "Financial literacy and financial sophistication in the older population". Journal of pension economics \& finance, 13(4), 347-366, 2014.

[43] Atalay, K., Bakhtiar, F., Cheung, S., \& Slonim, R. "Savings and prizelinked savings accounts". Journal of Economic Behavior \& Organization, 107, 86-106, 2014.

[44] Creswell, J. W. A concise introduction to mixed methods research. Sage Publications, 2014

[45] Israel, G. D. "Determining sample size 1". November 15, 1992.

[46] Baruch, Y., \& Holtom, B. C. "Survey response rate levels and trends in organizational research". Human Relations, 61(8), 1139-1160, 2008.

[47] FSD. "Fin Access Household Survey 2015". Retrieved from http://fsdkenya.org/publication/finaccess2016/

[48] Garson, G. D. "Testing statistical assumptions". Asheboro, NC: Statistical Associates Publishing, 2012.

[49] Allgood, S., \& Walstad, W. B. "The effects of perceived and actual financial literacy on financial behaviors". Economic inquiry, 54(1), 675697, 2016.

[50] Lamb, L. "Financial exclusion and financial capabilities in Canada". Journal of Financial Economic Policy, 8(2), 212-227, 2016.

[51] Claes, L., \& Müller, A. "Resisting temptation: is compulsive buying an expression of personality deficits?". Current Addiction Reports, 4(3), $237-245,2017$

[52] Hayes, A. F. Introduction to mediation, moderation, and conditional process analysis: A regression-based approach. Guilford Publications, 2013.

[53] Borau, S., El Akremi, A., Elgaaied-Gambier, L., Hamdi-Kidar, L., \& Ranchoux, C. "Analyzing moderated mediation effects: Marketing applications". Recherche et Applications en Marketing (English Edition), 30(4), 88-128, 2015.

[54] Hayes, A. F. "An index and test of linear moderated mediation". Multivariate behavioral research, 50(1), 1-22, 2015.

[55] Li, D., Zhou, Y., Li, X., \& Zhou, Z. "Perceived school climate and adolescent Internet addiction: The mediating role of deviant peer affiliation and the moderating role of effortful control". Computers in Human Behavior, 60, 54-61, 2016.

[56] Cronbach, L. J. "Coefficient alpha and the internal structure of tests". Psychometrika, 16(3), 297-334, 1951.

[57] Rovai, A. P., Baker, J. D., \& Ponton, M. K. Social science research design and statistics: A practitioner's guide to research methods and IBM SPSS. Watertree Press LLC, 2013.

[58] Sekeran, U. and Bougie, R. Research Methods for Business: A SkillBuilding Approach. 6th Edition, Wiley, New York, 2013.

[59] Zhao, X., Lynch Jr, J. G., \& Chen, Q. "Reconsidering Baron and Kenny: Myths and truths about mediation analysis. Journal of consumer research, 37(2), 197-206, 2010Jose, P.E. ModGraph-I: “A programme to compute cell means for the graphical display of moderational analyses: The internet version, Version 3.0". Victoria University of Wellington, Wellington, New Zealand, 2013,

[60] Shofawati, A. "The Role of Digital Finance to Strengthen Financial Inclusion and the Growth of SME in Indonesia". KnE Social Sciences, 389-407, 2019.

[61] Kaliappen, N., \& Hilman, H. "Does service innovation act as a mediator in differentiation strategy and organizational performance nexus? An empirical study". Asian Social Science, 10(11), 123, 2014.

[62] Kostopoulos, K., Papalexandris, A., Papachroni, M., \& Ioannou, G. "Absorptive capacity, innovation, and financial performance. Journal of Business Research, 64(12), 1335-1343, 2011.

[63] Lusardi, A., \& Mitchell, O. S. "Financial literacy around the world: an overview". Journal of pension economics \& finance, 10(4), 497-508, 2011.

[64] Xiao, J. J., \& Porto, N. "Financial education and financial satisfaction: Financial literacy, behavior, and capability as mediators". International Journal of Bank Marketing, 35(5), 805-817, 2017.

[65] Yang, S., Ishtiaq, M., \& Anwar, M. "Enterprise risk management practices and firm performance, the mediating role of competitive 
advantage and the moderating role of financial literacy". Journal of Risk and Financial Management, 11(3), 35, 2018.

[66] Achtziger, A., Hubert, M., Kenning, P., Raab, G., \& Reisch, L. "Debt out of control: The links between self-control, compulsive buying, and real debts". Journal of Economic Psychology, 49, 141-149, 2015. 